Journal of Education and Vocational Research

Vol. 5, No. 4, pp. 205-215, December 2014 (ISSN 2221-2590)

\title{
Instructional Supervision Factors Affecting Organizational Commitment of Thai Teachers: A Case Study of Amphur Mueang, Prachinburi Province, Thailand
}

\author{
Robina David Madriaga \\ Saint Theresa International College, Thailand \\ robi_angel18@yahoo.com
}

\begin{abstract}
This study is a descriptive research. The main purpose and objectives of this study were: 1) To determine the level of commitment of the teachers in terms of the three organizational commitment components namely affective, normative and continuance commitment; 2) To determine the level of instructional supervision as perceived by teachers in terms of its six factors namely inspection, assistance and support, oversight responsibilities, leadership skills, professional development, and collaboration; 3) To investigate the significance of instructional supervision factors affecting organizational commitment of Thai teachers. This study utilized descriptive method. The instrument employed for collecting the data was an opinionnaire regarding the factors of instructional supervision and components of organizational commitment developed by Baffour-Awuah (2011) and Meyer and Allen (1991).The statistics used for the treatment of data were mean, standard deviation (s.d.), standard error mean (s.e.mean), coefficient of variation (C.V.), and Multiple Regression Analysis. Results showed that two of the components of organizational commitment namely Affective Commitment and Normative Commitment are above the expected level or in high level, while Continuance Commitment is within the expected level or in moderate level. All six factors of instructional supervision are above the expected level or in high level. It was also found that among the six factors of instructional supervision, only two of them namely "Assistance and Support" and "Leadership Skills" significantly affect the organizational commitment of Thai teachers. The predictive equation is:
\end{abstract}

$\mathrm{Z}_{\text {(OrganizatönalCommiment) }}=5$ 59.506* $+1.748 *$ (Assistance and Support) + 1.697* (Leadership Skills); ${ }^{2}$ $=0.4710, \mathrm{~F}=51.202 *(10.025)(0.576)$

Keywords: Instructional Supervision, Organizational Commitment, Affective Commitment, Normative Commitment, Continuance Commitment

\section{Introduction}

Background of the study: Today's $21^{\text {st }}$ century challenge in improving the quality of education urges educators to continuously seek for educational reforms. Decentralizing the education system is one of the reforms that places school principals into the limelight of taking the responsibility for improving the quality of education which includes the empowerment of teachers by training and honing their skills and abilities through supervision (Barrera-Osorio, Fasih, Patrinos, \& Santibanez, 2009; Gamage \& Sooksomchita, 2004; Heredia-Ortiz, 2007). Various researches have shown that supervision has significant effect on the performance of a school. Researchers also believe that instructional supervision can aid in solving the problems of the education system which include the lagging performance of students during assessment. Moreover, they are also convinced that instructional supervision can improve and benefit school's growth, and teaching personnel. Additionally, results of studies revealed that instructional supervision can positively affect the classroom instructional processes and practices. It was also revealed that the engagement of supervisors and teachers for the purpose of improving instruction logically contribute to the improvement of the quality of education and to the development of the abilities of both the supervisor and the teachers (Sergiovanni \& Staratt, 2002). Researchers then recommended the need to improve instructional supervision of teachers (Charles, Kimutai, \& Zachariah, 2012).

Commitment of teachers to their school is another concern in the education system at present. High turnover and attrition rates among teachers greatly affect the performance of the schools which in turn affects the quality of education (Pitsoe \& Machaisa, 2012). Researchers believe that organizational commitment can lessen turnover and attrition, and eventually contribute to the success of an organization (Bakan, Büyükbeşe, \& Erşahan, 2011).Teachers' commitment to their school will allow them to help in the realization of the goals of their school. Encouraging teachers' retention by providing them 
empowerment that includes training and professional growth can influence their commitment (Bogler \& Somech, 2004). Researchers have proposed that when teachers are supported and given the assistance that they need, they are likely to be motivated to improve their instruction and remain in the teaching profession. (Hoy, Hanum \& Moran, 1998).

The support given by principals and other teachers to their colleagues and the commitment that these teachers have for the schools are linked and should be considered in the improvement of the quality of education (Hoy, Tarter \& Witkoskie, 1992). However, this link between the support and assistance received by teachers in their supervision and the commitment they have is not yet clear. Positive consequences, antecedents and factors that correlated with organizational commitment have been extensively researched. However, there are very few that could show that supervision of instruction is directly linked with the commitment of teachers. Moreover, in the local level, studies have been conducted in Thailand about factors that influence teacher's job satisfaction which is one of the correlates of organizational commitment. However, the level of organizational commitment of Thai teachers to their respective schools has not been explored. Additionally, there are very few studies that show the level of instructional supervision being practiced in Thai schools and most importantly, there are no studies conducted yet on the effect of instructional supervision regarding the commitment of Thai teachers towards their schools.

Statement of the problem: Educators' turnover and attrition rates as well as teachers' effectiveness and teaching skills and practices are now becoming a global phenomenon (Pretorius, 2012; Xaba, 2003). These are just some of the problems that pose a challenge to the education system. They do not only affect the teachers but also affect the performance of the school which is a factor of the improvement of the quality of education and thus should be addressed and taken seriously (Xaba, 2003). Some of the reasons of turnover and attrition of teachers are too little support from the administration and lack of influence and respect (Kopkowski, 2008). These reasons also include mentoring and training given to the teachers for their development. It has also been said that turnover and attrition are the results of low commitment of teachers to their profession and to their school (Xaba, 2003). These are just some of the many reasons that trigger teachers to leave their profession and their schools.

In Thailand, despite the effort of the government to improve the quality of education, there are still problems that persist. The National Research Council of Thailand has seen problems which include ineffective teachers and ineffective system of supervision that provides assistance and support to teachers. To combat such problems, the MOE of Thailand calls for the implementation of the King's philosophy on sufficiency economy in schools along with the 1999 National Education Act Amendment in 2003 (Pitak, Ariratana, \& Pimtong, 2013). This project revealed steps of work procedures which include supervision and coaching. Of particular focus is the supervision in schools for improving the quality of education, thereby, enhancing the teachers' capabilities of providing effective instruction. On the other hand, researchers revealed that turnover rates in Thai schools are also a problem (Espejo \& Eleguen, 2010). Based on the research conducted by Espejo and Eleguen (2010), the overall mean value for the turnover rate among the respondents in selected Catholic secondary schools in Nakornayok, Thailand is 2.59 or moderate. However moderate, this can still affect the performance of the school especially when those who are leaving are the qualified ones. The commitment and loyalty of the teachers to their school is highly regarded. Keeping qualified and bright teachers would contribute much to the improvement of the quality of education.

Thus, taking into consideration what keeps teachers to remain and commit themselves to their school is a very important matter to study together with the supervision of instruction that provides support, assistance and professional development to the teachers. There are various researches that have been conducted regarding instructional supervision and organizational commitment. However, there is little study conducted showing instructional supervision factors that affect organizational commitment which could support the aforementioned variables of this local study. This study will contribute to the body of knowledge about the nature, practices and level of instructional supervision and about the organizational commitment of primary and secondary Thai teachers teaching in public and private schools located in Mueang, Prachinburi. This study can also be the basis of further study regarding the factors that affect organizational commitment of teachers which particularly involve the factors of instructional supervision. 


\section{Research Questions}

1. What is the level of commitment of the teachers in terms of the following organizational commitment components:

1.1 Affective Commitment

1.2 Continuance Commitment

1.3 Normative Commitment

2. What is the level of instructional supervision as perceived by teachers in terms of the following factors:

2.1 Inspection

2.2 Assistance and Support

2.3 Oversight Responsibilities

2.4 Leadership Skills

2.5 Professional Development

2.6 Collaboration

3. What are the factors of instructional supervision that significantly affect the organizational commitment of primary and secondary Thai teachers?

Figure 1: Conceptual Framework of the Study
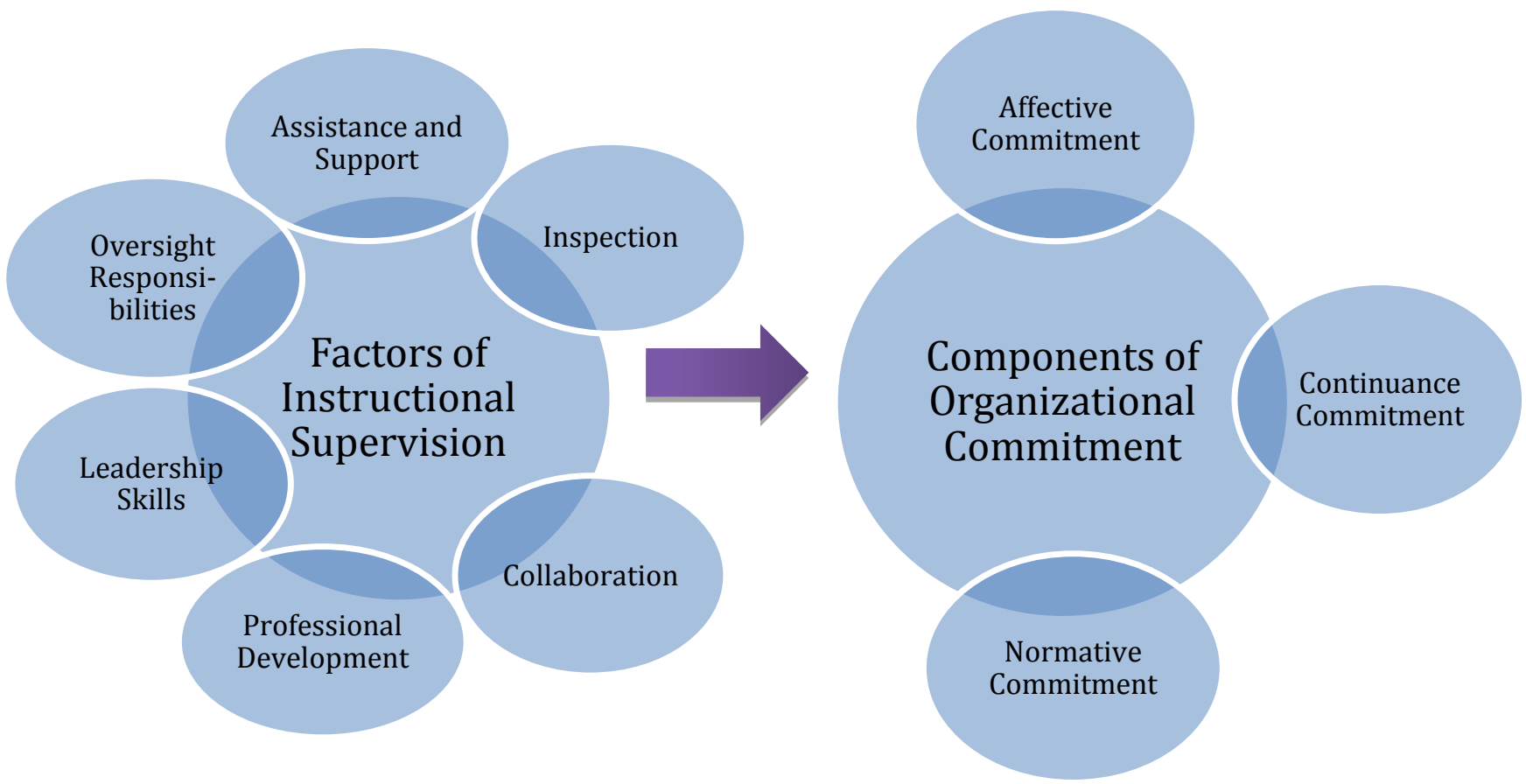

As shown in Figure 1, Instructional Supervision has six factors namely, Inspection, Assistance and Support, Oversight Responsibilities, Leadership Skills, Professional Development and Collaboration. Organizational Commitment has three components namely, Affective commitment, Continuance Commitment and Normative Commitment. A single-headed arrow is used to show the concept of affecting the organizational commitment.

\section{Literature Review}

Educational reforms have focused on improving the educational system. This leaves the major role of reformation to the school principals who stand as front liners and keys to transformation. Their roles are crucial to the improvement of the quality of education. Hence, it is very important to understand their duties and responsibilities as school administrators. There are several authors that have discussed and supported the roles of school principals as leaders, supervisors and agents of change. Some of these had focused on discussing the supervisory roles of school principals which showed its importance as an integral part of the daily process and operation in schools (Sharma, Yusoff, Kannan, \& Baba, 2011). Several authors also included discussion on the development of supervision from traditional to modern practices (Sullivan and Glanz, 2000). These authors showed that supervision as one of the tasks of school principals had begun as a process of external inspection done by an appointed citizen who would inspect 
teachers and students in school (Baffour-Awuah, 2011). School principals as supervisors were tagged as inspectors back then. As inspectors they have the responsibility of intervening directly in the work of teachers to correct their instructional practices and performance (Baffour-Awuah, 2011; Farley, 2010; Payne, 2010). However, supervision as inspection and as an educational practice had evolved through the years as population and number of schools grew starting from Western nations and through-out the Asian nations. Different models have been introduced by researchers and authors of books that were deduced from different studies conducted in finding supervision practices of heads of schools, and other organization (Daresh, 2006). Among the different models of supervision, Clinical supervision is the most widely used which was the original idea of Cogan and colleagues (Baffour-Awuah, 2012; Kamindo, 2008). Other contemporary models of supervision had emerged and sprung-out from Clinical supervision. Some of these are developmental supervision, differentiated model of supervision and collegial supervision (Glickman et al., 2007; Kamindo, 2008; Sergiovanni, 2009; Payne, 2010; Glatthorn, 1984; Sergiovanni \& Staratt, 2002).

There are also major studies conducted on the roles of school principals which showed the importance and impact of their roles as school administrators. Some of these studies have focused on the supervisory tasks of schools principals and the school practices effective on teachers and students (Blasé \& Blasé, 2000). These studies have showed the effectiveness and importance of the supervisory role of school principals towards the improvement of school's performance. Previous studies have also examined the perspective of teachers and school principal about how they experienced instructional supervision in their schools, their conceptualizations of instructional supervision, and aspects of instructional supervision they want to practice. In Baffour-Awuah's (2011) study concerning instructional supervision, he had listed six factors of instructional supervision he used in determining what aspect of instructional supervision teachers and school principals want to practice. These factors are inspection, assistance and support, oversight responsibilities, leadership skills, professional development and collaboration (Baffour-Awuah, 2011). Some studies also examined the supervisor's behavior, responsibilities and how they improve supervision (Blasé \& Blasé, 2000; Kutsyuruba, 2003; Baffour-Awuah, 2011). There are lots of essential roles of school principals. However, the most important part of their roles is how they execute and use them for the improvement not only of their schools and records but most importantly for the betterment of all their constituents specifically the staff, teachers and students. School is a significant organization in the society that consists of people working together in providing quality education. This includes the teachers whose loyalty and roles are also crucial in the improvement of the school's performance. Their commitment contributes to the success of their organization which is the school. Their commitment is very important that it results in valuable outcomes not only for their organization but also with themselves and with their employers (Azeem, 2010).

Seeing the valuable outcomes of employees' commitment and the importance of keeping competitive employees in organizations, the organizations themselves, especially the heads, are now faced with a challenge of keeping their employees (Manetje, 2009) for a more successful and productive organization. They are faced with the challenge on how they will be able to let their employees submit and commit their full potential in working together to achieve their goals. This also applies with school principals and teachers. Keeping competitive teachers is now a major problem. There are major researches that supported the concepts and importance of employees' commitment to their organization. Brown (2003) defined organizational commitment as the commitment of the employees to their respective organizations. It is also the extent which an employee recognizes himself with the organization and pertains to his willingness to continue with the organization (Rehman, Rehman, Saif, Khan, Nawaz, \& Rehman, 2013). There are also previous studies that discussed the components of organizational commitment (Meyer \& Allen, 1991; Jaros, 2007; Manetje, 2009). Meyer and Allen (1991) are just some of those researchers who have contributed to the development of the concept on organizational commitment. They had proposed a three-component model of organizational commitment which gained popularity among researchers. This three-component model that conceptualizes organizational commitment has three components namely affective, continuance, and normative commitment (Meyer \& Allen, 1991; Meyer, Stanley, Herscovitch, \& Topolnytsky, 2002; Jaros, 2007; Manetje, 2009). Some studies have also examined the antecedents, correlates and consequences of organizational commitment (Adebomi, Ibitoye, \& Sanni, 2012; Azeem, 2010; Meyer, Stanley, Herscovitch, \& Topolnytsky, 2002). For instance, studies conducted by several authors revealed that antecedent variables like the organization structure have been linked to organizational commitment. Decentralization and participation in decisionmaking is related to commitment specifically to affective commitment (Meyer \& Allen, 1991). Employees 
who feel they are part of the organization's decision-making tend to feel attached and affiliated with the organization which will make them stay in the organization.

Meta-analyses of previous studies on organizational commitment have also been conducted (Meyer, Stanley, Herscovitch, \& Topolnytsky, 2002). Job-related factors such as job satisfaction, job-involvement and occupational commitment were found to correlate with organizational commitment. In a study conducted by Adebomi, Ibitoye, and Sanni, (2012) involving special education teachers with their job commitment and job satisfaction, the results revealed that job satisfaction has positive significant relationship with commitment. It was also uncovered that job satisfaction was significant if used alone as the predictor of job commitment. On the other hand, the study conducted by Azeem (2010) involving job satisfaction and organizational commitment, the results revealed that the mean values of job satisfaction and organizational commitment are at moderate side. Results show a slightly significant positive relationship among job satisfaction and organizational commitment. Outcomes of organizational commitment such as turnover and withdrawal behaviors, absenteeism, job performance, organizational citizenship behavior, stress and work-family conflict are also revealed (Meyer, Stanley, Herscovitch, \& Topolnytsky, 2002; Manetje, 2009). These are the negative effects of low commitment to the organization. For instance the meta-analyses conducted by Meyer, Stanley, Herscovitch, and Topolnytsky, (2002) revealed that the correlation between turnover and all the three components of organizational commitment were all negative. Employees who have low organizational commitment tend to fall into disarray that leads them to be absent, show less enthusiasm in working and worse, leave the organization.

In effect, researchers have established a strong theoretical and conceptual base about instructional supervision and organizational commitment. However, there is a lack of empirical studies that have examined the effects of instructional supervision to teachers towards their schools. Similarly, there is a lack of research that shows factors of instructional supervision that affect organizational commitment of school teachers. Instructional supervision can improve teachers' performance which leads to the satisfaction of the teachers. Researchers have proposed that job satisfaction is one of the correlates of organizational commitment that influence the likelihood of employees to stay in their organization. Relatively little research however, has linked directly and focused on instructional supervision and organizational commitment. Therefore, this study sought to reveal the link between the two concepts specifically the effects that instructional supervision has on organizational commitment. It sought also to determine the factors of instructional supervision that affect the commitment of teachers.

\section{Methodology}

Research Design: This study used descriptive research method. The rationale for the use of this method is because the perception of teachers on the level of instructional supervision and of commitment to their current school is studied to determine the factors of instructional supervision that affect their commitment to their school. Moreover, this method is also used to find if there is a significant relationship between the factors of instructional supervision and the components of organizational commitment. This study administered an opinionnaire which was adapted from the studies of Baffour-Awuah (2011) and Meyer and Allen (1991) consists of 24 Likert-style questions items. It used a 0-10 rating scale, 0 as lowest and 10 as the highest. Purposive sampling method is used in choosing the schools. Purposive sampling is used due for the reason that this study surveys a large population. The details of the sample are shown in Table 1.

Table 1: Distribution of Respondents from the three schools selected.

\begin{tabular}{llll} 
Name of School & $\begin{array}{l}\text { Number } \\
\text { Opinnionaires Sent }\end{array}$ & $\begin{array}{l}\text { Total numbers } \\
\text { opinnionnaires }\end{array}$ & of retrieved \\
& & N & Percentage \\
\hline 1. Mary Witthaya Prachinburi School & 60 & 60 & $100 \%$ \\
2. Prachin Ratsadorn Amroong School & 40 & 33 & $82.5 \%$ \\
3. Anuban Prachinburi School & 25 & 25 & $100 \%$ \\
Total & 125 & 118 & $94.4 \%$ \\
\hline
\end{tabular}


The table shows the number of opinionnaires distributed among the respondents in the three selected private and public schools in Prachinburi. A total of 118 opinionnaires or $94.4 \%$ were retrieved among the 125 distributed opinionnaires. From Mary Witthaya Prachinburi School, 60 or $100 \%$ of the distributed opinionnaires were retrieved. In Prachin Ratsadorn Amroong School, out of 40 opinionnaires, 33 or $82.5 \%$ of the total were retrieved and the 25 opinionnaires sent to Anuban Prachinburi School were retrieved $100 \%$.

Research Instruments: Instruments created by Baffour-Awuah (2011) for the factors of instructional supervision and Meyer and Allen (1991) who are two of the original pioneers of the concept for the components of organizational commitment are adapted in this research opinionnaire's development. The adapted opinionnaires were slightly modified by the researcher by adding items to make the numbers of items for each factor and component even. The adapted opinionnaires are then translated to Thai and were distributed for pilot testing.

\section{Statistical Tools Used}

1. To determine the level of organizational commitment of teachers in terms of its three components namely, affective commitment, continuance commitment, and normative commitment, the basic statistical tools such as mean, standard deviation, standard error of mean and coefficient of variation were applied.

2. To determine the level of instructional supervision as perceived by teachers in terms of the following factors namely, inspection, assistance and support, oversight responsibilities, leadership skills, professional development and collaboration, the basic statistical tools such as mean, standard deviation, standard error of mean and coefficient of variation were applied.

3. To investigate the instructional supervision factors that significantly affect the organizational commitment of primary and secondary Thai teachers teaching in the three selected public and private schools located in Mueang, Prachinburi, Thailand, multiple regression analysis was applied.

Validity and Reliability Test: As regards to the validity of the items in the Opinionnaire on Instructional Supervision Factors and Components of Organizational Commitment, the researcher distributed these to 30 respondents who did not take part in the actual survey. The responses of these initial respondents were analyzed. Ambiguous items were changed, rephrased or simplified based on the recommendations of the expert validators. The Cronbach Alpha test was used to obtain the reliability coefficient of the Opinionnaire of the two variables of the study which are 0.927 and 0.967 , respectively or very high. The Cronbach Alpha test was used to obtain the over-all reliability coefficient of the Opinionnaire which is 0.967 or very high.

Data Collections Procedure: After the researcher had conducted pilot testing of the Opinionnaire to establish its validity and reliability, approval was obtained from the adviser to administer the Opinionnaire to the primary and secondary Thai teachers of the three selected private and public schools located in Namueang, Mueang District, Prachinburi, Thailand. Participants were asked to complete the opinionnaire which could take up to less than 20 minutes. The data were collected, organized and tabulated in preparation for analysis and interpretation. The following is the scale used for the Teacher's Commitment and Level of Instructional Supervision's Numerical Rating with the corresponding descriptive equivalent and description.

\begin{tabular}{lll}
\hline $\begin{array}{l}\text { Numerical Rating for Teacher's Commitment } \\
\text { Numerical Rating }\end{array}$ & $\begin{array}{l}\text { Descriptive } \\
\text { Equivalent }\end{array}$ & Description \\
\hline 8.00 and above & $\begin{array}{l}\text { Very High (VH) } \\
\text { High (H) }\end{array}$ & $\begin{array}{l}\text { The teacher's commitment is far above the expected level. } \\
\text { The teacher's commitment is above the expected level. }\end{array}$ \\
$\begin{array}{ll}\text { Moderate (M) } \\
4.00-5.99\end{array}$ & $\begin{array}{l}\text { The teacher's commitment is within the expected level. } \\
2.00-3.99\end{array}$ & $\begin{array}{l}\text { The teacher's commitment is below the expected level. } \\
1.99 \text { and below }\end{array}$ \\
\hline
\end{tabular}




\begin{tabular}{|c|c|c|}
\hline \multicolumn{3}{|c|}{ Numerical Rating for the Level of Instructional Supervision } \\
\hline $\begin{array}{l}\text { Numerical } \\
\text { Rating }\end{array}$ & $\begin{array}{l}\text { Descriptive } \\
\text { Equivalent }\end{array}$ & Description \\
\hline 8.00 and above & Very High (VH) & The level of instructional supervision is far above the expected level. \\
\hline $6.00-7.99$ & $\operatorname{High}(\mathrm{H})$ & The level of instructional supervision is above the expected level. \\
\hline $4.00-5.99$ & Moderate (M) & The level of instructional supervision is within the expected level. \\
\hline $2.00-3.99$ & Low $(\mathrm{L})$ & The level of instructional supervision is below the expected level. \\
\hline 1.99 and below & Very Low (VL) & The level of instructional supervision is far below the expected level. \\
\hline
\end{tabular}

\section{Data Analysis}

The data collected were coded and analyzed using the Statistical Package for Social Science (SPSS) Version 16.0 .

Table 2: The Basic Statistics on the Level of Organizational Commitment of Primary and Secondary Thai Teachers of the Three Selected Private and Public Schools located in Mueang District, Prachinburi

\begin{tabular}{|c|c|c|c|c|c|c|}
\hline \multirow{2}{*}{$\begin{array}{l}\text { Components of } \\
\text { Organizational Commitment }\end{array}$} & \multirow[t]{2}{*}{ Rank } & \multicolumn{4}{|c|}{ Basic Statistics } & \multirow{2}{*}{$\begin{array}{l}\text { Descriptive } \\
\text { Equivalent }\end{array}$} \\
\hline & & mean & s.d. & $\begin{array}{l}\text { s.e } \\
\text { mean }\end{array}$ & c.v. & \\
\hline 1. Affective Commitment & 1 & 61.75 & 13.41 & 1.23 & 0.2171 & High \\
\hline 2. Normative Commitment & 2 & 55.10 & 14.93 & 1.37 & 0.2710 & High \\
\hline 3. Continuance Commitment & 3 & 40.02 & 17.09 & 1.57 & 0.4269 & Moderate \\
\hline Total & - & 156.87 & 45.43 & 4.17 & 0.2896 & High \\
\hline
\end{tabular}

The results of data analysis in Table 2 show that two of the components of Organizational Commitment namely Affective Commitment and Normative Commitment are in high level with mean of 61.75, and 55.10 and standard deviation (s.d.) of 13.41 and 14.93, respectively. The teachers' commitments with regard to these components of Organizational Commitment are above the expected level. The Continuance Commitment, which is another component of Organizational Commitment, is in moderate level with mean of 40.02 and standard deviation (s.d.) of 17.09. With regards to this, teachers' commitment is within the expected level. The three components of Organizational Commitment have a total of 156.87 for the mean values and 45.43 for the standard deviation. By considering the C.V. values, it could be concluded that the three components of organizational commitment are inconsistent with C.V. values of $0.2171,0.2710$ and 0.4269 , respectively. These components of Organizational Commitment can be grouped into three groups. Affective Commitment in group 1; Normative Commitment in group 2 and Continuance Commitment in group 3. In terms of rank, based on the C.V. values, Affective Commitment is the first with C.V. value of 0.2171 , followed by Normative Commitment with C.V. value of 0.2710 and Continuance Commitment ranked as the last with C.V. value of 0.4269 .

Table 3: The Basic Statistics on the Level of Instructional Supervision as Perceived by the Primary and Secondary Thai Teachers of the Three Selected Private and Public Schools located in Mueang District, Prachinburi

\begin{tabular}{lllllll}
\hline & \multicolumn{9}{c}{ Basic Statistics } \\
Instructional Supervision & Rank & & s.d. & s.e & c.v & Descriptive \\
mean & & & & Equivalent \\
\hline 1. Assistance and Support & 1 & 27.81 & 7.36 & 0.68 & 0.2646 & High \\
2. Oversight Responsibilities & 2 & 27.15 & 7.45 & 0.69 & 0.2742 & High \\
3. Leadership Skills & 3 & 28.73 & 8.22 & 0.76 & 0.2862 & High \\
4. Collaboration & 4 & 27.72 & 7.97 & 0.73 & 0.2876 & High \\
5. Inspection & 5 & 26.32 & 7.87 & 0.72 & 0.2989 & High \\
6. Professional Development & 6 & 25.97 & 8.02 & 0.74 & 0.3090 & High \\
Total & - & 163.70 & 46.89 & 4.32 & 0.2864 & High \\
\hline
\end{tabular}


The results on Table 3 show that all six factors of instructional supervision are in high level of practice. Each factor was found to be highly practiced with mean values between 25.97 and 28.73 and standard deviation (s.d.) between 7.36 and 8.22. The six factors of instructional supervision have a total of 163.70 for the mean and 46.89 for the standard deviation (s.d.). By considering the C.V. values, it could be concluded that all of the six factors of instructional supervision are all inconsistent with C.V. values that lies between 0.2646 and 0.3090 . Based from their C.V. values, these factors of instructional supervision can be grouped into three groups. Assistance and Support and Oversight Responsibilities into group 1 with C.V. values 0.2646 and 0.2742 , respectively; Leadership Skills and Collaboration into group 2 with C.V. values 0.2862 and 0.2876, respectively; and Inspection and Professional Development into group 3 with C.V. values 0.2989 and 0.3090, respectively. Based on the C.V. values, Assistance and Support ranked first and is the most highly practiced factor of instructional supervision and Professional Development ranked the last and is the least practiced factor of instructional supervision.

Table 4: The Result of Multiple Regression Analysis of the Instructional Supervision Factors Affecting Organizational Commitment of the Primary and Secondary Thai Teachers in the Three Selected Private and Public Schools located in Mueang District, Prachinburi

\begin{tabular}{|c|c|c|c|c|c|c|c|c|c|c|}
\hline \multirow[b]{2}{*}{$\begin{array}{l}\text { Instructional } \\
\text { Supervision }\end{array}$} & \multicolumn{5}{|c|}{ Method Enter } & \multicolumn{5}{|c|}{ Method Stepwise } \\
\hline & B & $\begin{array}{l}\text { Std. } \\
\text { Error }\end{array}$ & Beta & $\mathbf{t}$ & $\begin{array}{l}\text { p- } \\
\text { value }\end{array}$ & B & $\begin{array}{l}\text { Std. } \\
\text { Error }\end{array}$ & Beta & $\mathbf{t}$ & $\begin{array}{l}\text { p- } \\
\text { value }\end{array}$ \\
\hline \multicolumn{11}{|l|}{ Constant } \\
\hline & 62.279 & 10.199 & - & $6.106^{*}$ & .000 & 59.506 & 10.025 & - & $5.936^{*}$ & .000 \\
\hline & .304 & .600 & .064 & .506 & .614 & & & & & \\
\hline \multicolumn{11}{|l|}{ Assistance and } \\
\hline $\begin{array}{l}\text { Support } \\
\text { Oversight }\end{array}$ & 1.421 & .775 & .282 & 1.835 & .069 & 1.748 & .576 & .347 & $3.037^{*}$ & .003 \\
\hline \multicolumn{11}{|l|}{ Responsibilities } \\
\hline \multicolumn{11}{|l|}{ Leadership } \\
\hline \multicolumn{11}{|l|}{ Professional } \\
\hline \multicolumn{11}{|l|}{$\begin{array}{l}\text { Development } \\
\text { Collaboration }\end{array}$} \\
\hline & .825 & .892 & .177 & .925 & .357 & & & & & \\
\hline R Square & 0.5020 & & & & & 0.4710 & & & & \\
\hline $\mathrm{F}$ & & & 18. & $579^{*}$ & & $51.202 *$ & & & & \\
\hline p-value & & & 0.0 & 00 & & 0.000 & & & & \\
\hline
\end{tabular}

By using method enter of multiple regression analysis; it was found that the linear combinations of the predictor variables (six factors of Instructional Supervision) were statistically significant to affect the organizational commitment of teachers with $\mathrm{F}$ value of 18.679, and p-value of 0.000 . However, the individual analysis of the predictor variables (six factors of Instructional Supervision) showed that none of the six factors was found to be statistically significant to affect the organizational commitment of teachers. It was also found that the coefficient of determination, $\mathrm{R}^{2}$, was 0.502 . It means that $50.20 \%$ of the variation in the criterion variables (Components of Organizational Commitment) was accounted for by the linear combinations of the predictor variables or the six factors of Instructional Supervision. By using method stepwise of multiple regression analysis, it was found that only two predictor variables (six factors of Instructional Supervision) namely, Assistance and Support and Leadership Skills were the necessity and sufficient factors to affect "Organizational Commitment" with $\mathrm{t}$ values of 3.037* and 3.293* respectively. It was found also that $47.10 \%$ of the variation on the criterion variable or organizational commitment was accounted for by the linear combinations of the two predictor variables (factors of instructional supervision).

\section{The predictive equation is:}

$y=62.279^{*}+0.304$ (Inspection) +1.421 (Assistance and Support) -1.359 (Oversight Responsibilities)
(10.199) (0.600)
(0.775)
$(0.715)$ 
+ 1.271(Leadership Skills) + 0.948(Professional Development) + 0.825 (Collaboration);

(0.654) (0.810)

(0.892)

$\mathrm{R}^{2}=0.5020, \mathrm{~F}=18.679^{*}$

With standard equation:

$Z_{\wedge}=59.506^{*}+0.748^{*}$ (Assistance and Support) $+1.697^{*}$ (Leadership Skills); $\mathrm{R}^{2}=0.4710, \mathrm{~F}=51.202^{*}$

(10.025) (0.576)

Discussion and Summary of Findings: The findings of the study are presented as follows:

- The level of Organizational Commitment of primary and secondary Thai teachers teaching in the three selected public and private schools located in Mueang District, Prachinburi in terms of the components Affective Commitment and Normative Commitment is above the expected level or is in high level. It means that the Thai teachers are highly committed in terms of the two components of organizational commitment namely Affective Commitment and Normative Commitment. While in terms of Continuance Commitment, teachers' level of organizational commitment is within the expected level or is in moderate level. It means that the Thai teachers are moderately committed to their school in terms of Continuance Commitment.

- The level of Instructional Supervision as perceived by the primary and secondary Thai teachers teaching in the three selected public and private schools located in Mueang District, in Prachinburi in terms of its six factors namely Inspection, Assistance and Support, Oversight Responsibilities, Leadership Skills, Professional Development, and Collaboration is above the expected level or is in a high level. It means that all the six factors of instructional supervision are highly practiced by their school principals.

- Using method enter of multiple regression analysis, the results show that there is no factors of Instructional Supervision that affect the Organizational Commitment of the primary and secondary Thai teachers of the three selected public and private schools located in Mueang District, Prachinburi Province. However, when analyzed with method stepwise of multiple regression analysis, two of the factors of Instructional Supervision namely Assistance and Support, and Leadership Skills affect the Organizational Commitment of the primary and secondary Thai teachers of the three selected public and private schools in Mueang District, Prachinburi. It means that out of six factors of instructional supervision, only two factors significantly affect the organizational commitment of teachers.

- The factors of Instructional Supervision significantly affect Organizational Commitment of the primary and secondary Thai teachers teaching in the three selected public and private schools in Mueang District, Prachinburi.

- The factors of Instructional Supervision namely Inspection, Assistance and Support, Leadership Skills and Collaboration affect the Organizational Commitment of Thai teachers in terms of Affective Commitment, while Professional Development affects the Organizational Commitment of Thai teachers in terms of Continuance Commitment, and the factors of instructional supervision namely Assistance and Support, and Leadership Skills affect the Organizational Commitment of Thai teachers in terms of Normative Commitment.

\section{Conclusion}

Based on the foregoing findings, the following conclusions are drawn:

- The primary and secondary Thai teachers teaching in the three selected public and primary schools located in Mueang District, Prachinburi are highly committed in terms of Affective and Normative Commitment and are moderately committed to their schools in terms of Continuance Commitment. 
- The factors of Instructional Supervision are in high level of practice as perceived by the primary and secondary Thai teachers teaching in the three selected public and private schools located in Mueang District, Prachinburi.

- Factors of Instructional Supervision like Assistance and Support, and Leadership Skills highly and significantly affect the Organizational Commitment of the primary and secondary Thai teachers teaching in the three selected public and private schools located in Mueang District, Prachinburi.

- Factors of Instructional Supervision significantly affect the Organizational Commitment of the primary and secondary Thai teachers teaching in the three selected public and private schools located in Mueang District, Prachinburi.

- Factors of Instructional Supervision like Inspection, Assistance and Support, Leadership Skills and Collaboration highly and significantly affect the Affective Commitment of the Thai teachers teaching in the three selected public and private schools located in Mueang District, Prachinburi.

- The Professional Development factors of Instructional Supervision highly and significantly affect the Continuance Commitment of the Thai teachers teaching in the three selected public and private schools located in Mueang District, Prachinburi.

- Assistance and Support, and Leadership Skills factors of Instructional Supervision highly and significantly affect the Normative Commitment of the Thai teachers teaching in the three selected public and private schools located in Mueang District, Prachinburi.

Recommendations: Based on the foregoing findings and conclusions, the following recommendations are offered:

- The level of Instructional Supervision as perceived by the primary and secondary Thai teachers teaching in the three selected public and private schools is above the expected level or is in a high level. However, among the factors, Professional Development ranked as the last, therefore, administrators should give more attentions on providing programs and activities that give teachers chances to develop their professional skills.

- Since factors of instructional supervision significantly affect organizational commitment of teachers, administrators should maintain and determine approaches on how to increase the level of organizational commitment of their teachers.

- Administrators should be more aware of their supervisory tasks especially on the teaching and learning practices and development of teachers.

- The future researchers could replicate this study using variables not covered by this study.

\section{References}

Adebomi, 0., Ibitoye, H. \& Sanni, 0. (2012). Job Satisfaction and self-efficacy as correlates of job commitment of special education teachers in Oyo State. Journal of Education and Practice, 3(9), 95-103.

Azeem, S. M. (2010). Job Satisfaction and Organizational Commitment among Employees in the Sultanate of Oman. Journal of Psychology, 1, 295-299.

Baffour-Awuah, P. (2011). Supervision of Instruction in Public Primary Schools in Ghana: Teachers' and Head teachers' Perspectives. Murdock University.

Bakan, I., Büyükbeşe, T. \& Erşahan, B. (2011). An investigation of organizational commitment and education level among employees. International Journal of Emerging Sciences, 1(3), 231-245.

Barrera-Osorio, F., Fasih, T., Patrinos, H. \& Santibanez, L. (2009). Decentralized Decision-making in schools: The theory and evidence on School-Based Management. The International Bank for Reconstruction and Development/ the World Bank. NW.

Blasé, J. \& Blasé, J. (2000). Effective Instructional Leadership: Teachers' perspectives on how principals promote teaching and learning in schools. Journals of Educational Administration, 38(20), 130141.

Bogler, R. \& Somech, A. (2004). Influence of teacher empowerment on teachers' organizational commitment, professional commitment and organizational citizenship behavior in schools. Teaching and Teacher Education, 20(3), 277-289.

Brown, B. B. (2003). Employees' Organizational Commitment and Their Perception of Supervisors' Relations-Oriented and Task-Oriented Leadership Behaviors. Virginia Polytechnic Institute and State University. 
Charles, T., Kimutai, C. K. \& Zachariah, K. (2012). The Impact of Head Teachers' supervision of Teachers on Students' Academic Performance. Journal of Emerging Trends in Educational Research and Policy Studies(JETERAPS), 3(3), 299-306.

Daresh, J. C. (2006). Leading and Supervising Instruction. Corwin Press. New York.

Espejo, A. C. \& Eleguen, E. (2010). Job Satisfaction and turnover rates of teachers in selected Catholic secondary schools in Nakhonnayok, Thailand. International Conference on Business \& Management Education (ICBME), 2(1).

Farley, G. (2010). Instructional Supervision: A Descriptive study focusing on the Observation and Evaluation of Teachers in Cyber Schools- Indiana University of Pennsylvania.

Gamage, D. \& Sooksomchita, P. (2004). Decentralization and School-based Management in Thailand. International Review of Education, 50(314), 289-305.

Glatthorn, A. (1984). Differentiated Supervision. Educational Resources Information Center.

Glickman, C. D., Gordon, P. S., \& Ross-Gordon, J. M. (2007). Supervision and instructional leadership: A developmental approach (7th Ed.). Boston: Pearson.

Heredia-Ortiz, E. (2007). The Impact of Education Decentralization on Education Output: A Cross Country Study. Economics Dissertations. Paper 21.

Hoy, W., Tarter, C. \& Witkoskie, L. (1992). Faculty trust in colleagues: Linking the Principal with school effectiveness. Journal of Research and Development in Education, 26, 38-45.

Hoy, W., Hanum, J. \& Moran-Tschannen, M. (1998). Organizational Climate and achievement: A parsimonious and longitudinal view. Journal of School Leadership, 8, 336-372.

Jaros, S. (2007). Meyer and Allen Model of Organizational Commitment: Measurement issues. The Icfai Journal of Organizational Behavior, 6(4), 7-25. Retrieved: April 28, 2013

Kamindo, C. M. (2008). Instructional supervision in an era of change: policy and practice in primary education in Kenya. Durham Theses. Durham University.(http://etheses.dur.ac.uk/2195/

Kopkowski, C. (2008). Why They Leave. National Education Association (NEA).neatodayhttp://www.nea.org/home/12630.htm

Kutsyuruba, B. (2003). Instructional Supervision: Perceptions of Canadian and Ukrainian Beginning High School Teachers. University of Saskatchewan, Saskatoon.http://www.collectionscanada.gc.ca/obj/54/f2/dsk3/ssu/TC_ssu_09052003134303. pdf.

Manetje, 0. M. (2009). Organizational Commitment, 37-59 Retrieved May 3, 2013 from http://www.uir.unisa.ac.za/bitstream/handle/10500/1133/04chapter3.pdf

Meyer, J. \& Allen, N. (1991). A three-component conceptualization of organizational commitment. Human Resource Management Review, 1(1), 61-89. Retrieved: May 6, 2013

Meyer, J., Stanley, D., Herscovitch, L. \& Topolnytsky, L. (2002). Affective, continuance, and normative commitment to the organization: a meta-analysis of antecedents, correlates, and consequences. Journal of Vocational Behavior, 61, 20-52. Retrieved: June 6, 2013

Payne, E. (2010). Implementing Walkthroughs: One School's Journey. Falls Church, VA.

Pitak, N., Ariratana, W. \& Pimtong P. (2013). Teacher Professional Development for Learning Organization on Sufficiency Economy in Small Schools. The European Journal of Social \& Behavioral Sciences, 4(55), 884-853.

Pitsoe, V. \& Machaisa, P. (2012). Teacher attrition catastrophe in Sub-Saharan Africa: A hurdle in the achievement of UPE, EFA Policy goals and MDGs. Science Journal of Sociology and Anthropology, Volume 4(2),2012, Article ID sjsa-215, 7 Pages, 2012. Doi: 10.7237/sjsa/215.

Pretorius, S. G. (2012). The Implications of Teacher Effectiveness Requirements for Initial Teacher Education Reform. Journal of Social Sciences, 8(3), 310-317.

Rehman, K., Rehman, Z., Saif, N., Khan, A., Nawaz, A. \& Rehman, S. (2013). Impacts of job satisfaction on organizational commitment: a theoretical model for academicians in HEI of developing countries like Pakistan. International Journal of Academic Research in Accounting, Finance and Management Sciences, 3(1), 80-89.

Sergiovanni, T. S. \& Staratt, R. J. (2002). Supervision: A redefinition. Boston, MA: McGraw-Hill.

Sergiovanni, T. J. (2009). The Principalship: A reflective practice perspective. Boston: Pearson Educational Inc.

Sharma, S., Yusoff, M., Kannan, S. \& Baba, S. (2011). Concerns of Teachers and Principals on Instructional Supervision in Three Asian Countries. International Journal of Science and Humanity, 1(3), 214217.

Sullivan, S. \& Glanz, J. (2000). Supervision that improves teaching: Strategies and techniques. Thousand Oaks, CA: Corwin Press Inc.

Xaba, M. I. (2003). Managing teacher turnover. South African Journal of Education, 23(4), 287-291. 